\title{
Quality of life for children with autism. Legislation and public policies
}

\section{Atalia ONIŢIU`, Sergiu-Lucian RAIU•}

\begin{abstract}
The present contribution discusses the legislation referring to persons diagnosed with Autistic Spectrum Disorders (ASD). From international documents (The Charter for Persons with Autism, the Convention on the Rights of Persons with Disabilities), to national legislation (The Law on Autism, The Methodological Norms for Applying the Law on Autism), we show these are still perfectible. We underline although there is a Romanian legislation for people with ASD, this is insufficiently known by parents of children with ASD, thus affecting the chances of children's evolution. Some legislation articles are partially or incomplete respected in our country, and the equality of chances for autistic adult is missing, with no access to specialized services or labor market. Romanian legislation insufficiently regulates and does not establish any clear procedure to ensure access to specialized recovery services (medical, social, educational) for persons with ASD, the screening for early detection of ASD symptoms and periodical evaluations for children are not performed, and more, legislation infringes the right to education and work for people with ASD.
\end{abstract}

Keywords: autism; legislation; rights, education; discrimination.

\section{Introduction}

Autism, together with its „alternatives” (ASD, atypical autism, Asperger syndrome), whose definitions may be also found in the Methodological Norms of the Law 151 from July 12 , 2010 (art. 1, parag. a-d)2, represents a developmental disorder with a causality

- Lecturer PhD, West University of Timisoara, Faculty of Sociology and Psychology, Department of Sociology, atalia.onitiu@e-uvt.ro.

- Associate assistant, Babeş-Bolyai University of Cluj-Napoca, Faculty of Sociology and Social Work, Department of Social Work, raiu.sergiu@yahoo.com

2a) "Infantile autism or autistic disorder is a pervasive developmental disorder characterized by permanent impairment of socially-related capacity, through a deviation of communication and restrictive, stereotypical behavioral patterns. Early onset (before the age of 3) by manifesting disturbances or deviations that concern at least three areas of development: 1 . Deficiency in initiating and developing social relationships, expression of interest and emotions; 2 . Inability to use language and communication; 3. presence of stereotypical behavior, including a restrictive and repetitive behavioral repertoire; b) Autistic Spectrum Disorder (TSA) or atypical autism is a pervasive developmental disorder with the same characteristics as Autistic Disorder, which causes deterioration or deficiency in relationship, communication and behavior, but which does not meet all the necessary criteria for the diagnosis of the autistic disorder or infantile autism. Pervasive 
extremely debated, both by media and specialty literature. The last evidences, disseminated (quite insufficiently we consider to Romanian audience) by the Association Autism Europe $^{3}$, show that "there is no scientific evidence showing a causal association between autism and vaccination;rates of early gastrointestinal disorders prior to diagnosis are not higher in children with ASD than in thegeneral population; there are no differences in the urinary profiles of children with ASD and a recentgroup control study does not justify the use of casein and gluten exclusion diets" (Barthelemy et al., 2000).

No matter the causes that determine this disorder, the impact on the families is overwhelming. In a recent study, conducted in four European countries, each with a different approach for people with ASD (United Kingdom, France, Poland and Spain), it is pointed out that families of children with autism/ASDare facing "high health expenditure and out of pocket payments for noncovered health services to low employment prospects, poor mental health, anxiety and wellbeing problems". The access to education for these children is fundamental in order to increase their quality of life, autonomy and insertion in society (Roleska et al., 2018, 2).

At the European Parliament meeting from November 6th, 2012 other issues that people with ASD are facing with: less that $10 \%$ of people with ASD can get a job compared with $45 \%$ of those with a disability and $65.8 \%$ of people without a disability; people with ASD are not considered potential members of society, their diagnosis is often inadequate, they do not benefit of proper education and training in order to apply for a job. "They are invisible, without proper support, have no choices, opportunities or future, only to live in segregation" (Morgan et al., 2012).

Developmental Disorder Not Alternately Specified (PDD) is used when there is pervasive and severe deterioration in the development of mutual social interaction or non-verbal or verbal communication skills, or when stereotyped behaviors, interests and activities are present, but the criteria for a pervasive specific development disorder, for schizophrenia, for schizotypal personality disorder, or for an avoidant personality disorder are not met; c) Asperger's syndrome is a pervasive developmental disorder that is characterized by an impairment of social behavior, social interaction, by the existence of restrictive, stereotypical concerns and interests, specific to autism; these people have a good cognitive and language function, with age-specific characteristics, but have a high incapacity for emotional resonance, expressing emotional reciprocity, empathic communication; d) Mental retard refers to the presence of a substantial limitation of neuropsychiatric functions. It is defined by the incomplete development of intelligence, characterized by the lack of cognitive, communication, motor and social skills, process that has emerged during the development period".

${ }^{3}$ Headquartered in Belgium, the association brings together representatives of 80 organizations from 30 European countries, its purpose being to improve the quality of life of children with autism and their families (www.autismeurope.org). 
The first European act that acknowledges the distinct nature of autism (when it was thought 1 million EU citizens may be affected by autism, and now estimated to be 3 million)and the necessity for specific measures for people with this diagnosis is The Charter for Persons with Autism, adopted as a Written Declaration by the European Parliament on May 9th, 1996. The Charter stipulates, in its 19 points, the fundamental rights of people with autism, arising from previous documents, such as The United Nations declaration on the Rights of Mentally Retarded Persons (1971) and the Rights of Handicapped Persons (1975) (Autism-Europe, 1996).

An important step taken at European level from a legislative point of view to support children with autism was The Convention on the Rights of Persons with Disabilities, adopted on December 13th 2006 and signed by all EU countries (including Romania). Although the Convention does not explicitly refer to autism, but this is considered a disability among others, its merit is that it requires the signatory countries to respect the right to education for people with disabilities (including autism). The same right is stated by the European Disability Strategy 2010-2020, adopted in 2010 by the European Commission, supporting inclusive education (E.C., 2010).

The Written Declaration on Autism, adopted by the European Parliament in 2015 and co-signed by 418 Members (Bilde et al, 2016)supports the importance of diagnosis and early intervention, and also the importance of a European strategy for autism (unfortunately still missing) (Roleska et al., 2018, 8-9).

At European level there is already a strategy on people with disabilities (European Disability Strategy 2010-2020), carried out when"one in six people in the European Union (EU) has a disability, making around 80 million who are often prevented from taking part fully in society and the economy because of environmental and attitudinal barriers. For people with disabilities the rate of poverty is $70 \%$ higher than the average partly due to limited access to employment. Over a third of people aged over 75 have disabilities that restrict them to some extent, and over 20\% are considerably restricted. Furthermore, these numbers are set to rise as the EU's population ages. Access to mainstream education for children with severe disabilities is difficult and sometimes segregated. People with disabilities, in particular children, need to be integrated appropriately into the general education system and provided 
with individual support in the best interest of the child. Lower participation in general education and in the labor market lead to income inequalities and poverty for people with disabilities, as well as to social exclusion and isolation. They need to be able to benefit from social protection systems and poverty reduction programmes, disability-related assistance, public housing programmes and other enabling services, and retirement and benefit programmes"(European Commission, 2010).

The need and importance for a European strategy for ASD has already been stated by the European Parliament on November 6th, 2012, having as a good practice example Wales, with a strategy already adopted in 2006-2007, followed by Northern Ireland: "Right across the globe we have all these laws, rules and regulations and yet still we are sitting around the tables trying to find the way forward. We don't need any more declarations, what we need is action and we need to have strategies for autism in each country, as well as local and national strategies. This must be directed from a European strategy for autism" (Pat Matthews) (Morgan et al., 2012).

In this context, on December 2nd the European Commission proposed a European Accessibility Act, which will set common accessibility requirements for certain key products and services that will help people with disabilities at the EU level to participate fully in society. In September 2017 the Parliament adopted its final position on the Act before starting negotiations with theCouncil (Autism Europe, 2016).

The European Parliament Written Declaration on Autism (2015), underlines the necessity for a European strategy to "support accurate detection and diagnosis across Europe; promote evidence-based treatment and support for all ages; foster research and prevalence studies; encourage the exchange of best practices" (Bilde et al, 2016).

\section{Romania's situation}

Although it is not explicitly addressed to children with autism, Decision 1251/2005on some measures to improve learning, instruction, compensation, recovery and special protection activities for children/pupils/young people with special education requirements within the special and specially integrated education system provides classes/groups of autistic children in the special and specially integrated education system (art. 1, parag. d), 
practically admitting the particularity of this disorder and the need for a special approach within the other disabilities.

Children with autism enter, though again, without a clear nomination, under the incidence of Law 448/2006on protection and promotion of rights for people with handicap, that, from the beginning, aims to ensure integration and social inclusion for people with handicap(art. 1), arguing among others (art. 3): equality of chances (let. c); equality of treatment for employment (let. d); accountability of community (let. f); adaptation of society for people with handicap (let. h); protection against neglecting and abuse (let. n). Article 7, parag. 2 says that: „Based on the principle of equalizing opportunities, competent public authorities are required to provide the necessary financial resources and to take specific measures to ensure that people with disabilities have direct and unhindered access to services”, while article 8, parag. 1 says that „National Authority for People with Handicap and the other central and local public authorities are required to ensure, according the present legislation, the necessary conditions for integration and social inclusion of persons with handicap". These two articles are, unfortunately, partially and incomplete respected in our country (Ștefănescu, Oșvat, 2011).

The first Romanian document strictly addressed to people with ASD is Law 151/2010,applied from January 1st, 2011, completed by the Methodological Norms. The Law is, unfortunately, partial and even discriminatory; as stated in the introduction „its purpose is to regulate special integrated health, education and social services, aiming to early diagnose, treatment, recovery and improving the quality of life and social function for people with ASD and associated mental health disorders, services provided by a specialized multidisciplinary team”, completing in cap. II, art. 4, parag. 1, that,early diagnosis is conducted for children between 0-3 years, according to standards established by the methodological norms of the present law", in other words excludes from diagnosis people over the age of 3 .

Although Law151/2010 claims that „health, education and social integrated special services are the following: active early detection, clinical psychiatric diagnosis and clinical psychological evaluation, psycho-pharmacological treatment, early specialized interventions, cognitive behavioral psychotherapy, counseling for parents and family" (chap. I, art. 2), and 
„the multidisciplinary specialized team from mental health centers, as well as other medical services suppliers from public or private health units comprises: specialist doctors in pediatric psychiatry, clinical psychologists, psychotherapists, psycho-pedagogues, speech therapists, kinetotherapists, educators and social worker; continue and monitor treatment is performed by specialist doctors in pediatric psychiatry and/or clinical psychologists and /or psychotherapists in public or private health units" (chap. I, art. 3, parag. 1-2), neither the Law 151/2010, nor the Methodological norms forLaw 151/2010regulate and establish any procedure to ensure access to services and establishment of this multidisciplinary team.

The methodological norms also include some provisions most parents in Romania could state as utopian, such as art. 3, parag. 1 and 2: „early detection is achieved through the ASD and associated mental health disorders screening and represents a professional medical service provided by the family medicine doctor (...) early detection is achieved for the entire pediatric population, ranging from 0-3 years, based on a screening questionnaire that will be applied at compulsory periodical evaluations from 12, 15, 18, 24, 36 months by the family doctor of the child". Although the law practically binds family doctors to perform early detection screening for ASD signs, this is not happening, moreover, most periodical evaluations are made on parents' request. Maybe if parents knew the legislation, they would become also aware of these aspects, essential for their children's future evolution. Very useful for parents, especially for those of children with ASD, would be to know the articles 4 and 5 from Law 151/2010, that explain in detail the entire procedure to follow for diagnosing and then accessingspecial therapeutic services ${ }^{4}$.

\footnotetext{
${ }^{4}$ Art. 4. (1) The infantile autism, ASD or Asperger syndrome diagnosis, as well as other associated mental health disorders diagnosis are established by the specialist doctor, according to European diagnosis criteria. The diagnosis, evaluation and reevaluation are performed in the ambulatory service, in the mental health center, individual medical practices or after hospitalization in a profile section. (2) Psychiatric evaluation and psychiatric diagnosis are made by the doctor specialized in pediatric psychiatry.(3) In order to receive an infantile autism, ASD or Asperger syndrome diagnosis, as well as other associated mental health disorders diagnosisthe following are required:psychiatrically evaluation, psychological evaluation, and, as the case, paraclinical evaluations, on specialist recommendation. (4) The psychiatric assessment is made by the specialist according to the medical standards in force. (5) The psychological evaluation necessarily precedes the medical diagnosis and is performed, upon the recommendation of the specialist physician, by a psychologist certified in clinical psychology, under the conditions of Law no. 213/2004 on exercise on the profession of psychologist with right of free practice, the establishment, organization and functioning of the College of Psychologists in Romania, with subsequent amendments, and the subsequent normative acts thereof.(6) After integrating the information obtained from psychological assessment, paraclinical examinations and interdisciplinary consultations, as the case may be, the specialist physician establishes the psychiatric diagnosis, the psychopharmacological treatment and make recommendations to the professionals providing services complementing the medical act, as the case may be: a) services related to the medical act; b) appropriate educational services for school and professional guidance; c) public social assistance services.(7) The
} 
After a rigorous analysis of Law 151/2010 and of Application Norms, the Association

\author{
ANCAAR Iași and the Foundation „Salvation Anchor” (Holland) suggested the Ministry of \\ Health a series of measures to improve the quality of life for children with autism, including \\ at least partial discount of therapies, the answer received being that:,the economic and \\ financial conditions do not allow the allocated budget to be sufficient to cover the entire cases
}

specialist physician informs the family about the diagnosis and the necessary therapeutic procedures for empowerment and / or rehabilitation. (8) At the request of the parents / legal representative, the specialist physician supplements the A5 medical certificate, namely the A5 medical certificate for children with disabilities. (9) The application form for the issue of the medical certificate type A5 is provided in Annex no. 2 which is an integral part of the present methodological norms.(10) The medical certificate form A5 is provided in Annex no. 3 which is an integral part of the present methodological norms.(11) The specialist physician informs the family doctor, by medical letter sent directly or through his / her parents / legal representative, about the diagnosis and the treatments performed and recommended. The specialist physician finalizes the medical act, including the issue of the medical prescription for medications with or without a personal contribution, as the case may be, of the paraclinic ticket, if the conclusions of the medical examination require. (12) The medical letter is a standardized document, which will be drawn up in two copies, one of which will remain at the specialized doctor, and one copy will be sent to the family doctor directly or through the parents / legal representative. The medical letter contains the number of the contract concluded with the health insurance house for the provision of medical services and is used only by the doctors performing the activity under this contract. (13) The model of the medical letter is laid down in the implementing provisions of the framework contract on the conditions for the provision of healthcare under the social health insurance scheme. (14) Access to specialized interventions is based on the recommendation of the medical specialist who made the diagnosis.(15) Family doctors highlight patients with the diagnosis of infantile autism, autistic spectrum disorder and Asperger syndrome and the diagnosis of other associated mental health disorders. Art. 5. (1The therapeutic intervention plan will be developed and supervised by the accredited professional in specific behavioral therapy techniques for persons with autistic spectrum disorder. (2) The specific behavioral intervention plan has specific intervention objectives and is achieved by: a) activities under each specific objective, focusing on social skills, language, attention and compliance; b) modeling, reinforcement and generalization methods used in the implementation of activities, which should support learning as much as possible. (3) The objectives of the specific behavioral therapeutic intervention plan provided in paragraph (1) should aim to: a) develop attentive, imitation and game skills; b) development of functional communication skills; these include language and communication alternatives, such as the image system, gestures and signs; c) learning social skills in an appropriate environment; d) learning daily life skills, such as using the toilet, washing, eating; e) management of sensory difficulties; f) Generalization of learning strategies to new situations and new people; g) management of undesirable behaviors; h) recognition and expression of emotions.(4) The specific interventions are: a) Behavioral interventions - the application of the principles of learning and the development of skills, efficacy techniques in scientifically proven TSAs validated by the international community; b) interventions to develop social and emotional abilities; c) sensory and motor development interventions; d) Developing parental and family competencies to support the child in developing skills. (5) Specialized interventions can be performed individually and / or in groups according to the needs of the person with TSA. The certified psychologist in behavioral techniques specific to children with TSA will determine how to perform the intervention. (6) The interventions are provided by professionals proving training and accreditation in their application, according to the standards developed by the College of Psychologists in Romania. (7) The specialized interventions have the following characteristics: a) they are carried out by professionals accredited in collaboration with the family and by the direct involvement of the family. Through support and information, the family will participate in the development of the child's social skills and the management of repetitive and difficult behaviors; b) are based on a behavioral functional analysis that includes the identification of the behaviors and skills to be taught to the person diagnosed with TSA and associated mental health disorders; c) are based on integrating and correlating behavioral analysis with social and educational services according to the specific needs of the person with TSA and related mental health disorders; d) include mandatory assessment of cognitive, social and emotional functioning before, during and after the intervention; the systematic evaluation is performed at 6 months and includes results of individual assessments (pediatric psychiatrist, clinical psychologist and other specialists as appropriate), and progress / regression is quantified using internationally validated scales, validated on Romanian population. (9) The specialized interventions will be carried out: a) in public or private accredited social services, in accordance with the legal provisions in force; b) in the child's educational environment, such as: nursery, kindergarten, school; c) at the child's home or in its development environment, including through mobile teams; d) by training the family members who are an integral part of the intervention. 
of children with ASD, aged between 2 and 18; the association of this disorder to other diseases, the persistency of some symptoms along the entire life, the severe implications over the entire family, will make the extent, duration and costs for treatment to be very high; clinical experience has proved that human and material efforts are rewarded only if the educational program specific for ASD is initiated between the age of 1 and 5; the initiation of the program after the age of 6 might bring improving for a smaller number of children" (apud Gherca, 2011).

In a presentation approaching the autistic people legislation in Romania, at a conference held in Focșani in 2011, the president of ANCAAR Iași, Carmen Gherca criticized Law 151/2010 and the Norms, pointing out that these do not ensure the required framework to respect the rights of people with autism, established by the The Charter for Persons with Autism (1996), arguing that the law establishes only early detection and intervention services, excluding people with ASD aged over 6, violating these persons rights for education and work. On the same occasion, Carmen Gherca highlighted the contrasting reality with the provisions of the Romanian legislation, starting with the Romanian Constitution. Lack of specialized training for teachers in mass schools makes the access of children with ASD to integrated education extremely restricted, sometimes non existing, and the equality of chances for an autistic adult is missing, because this diagnosis disappears after the age of 18 , thus the access to specialized services and to labor market not being ensured (Gherca, 2011).

Law 151/2010 occurs in the context in which, during August 2009, INSOMAR made a survey onthe „Discrimination phenomenon in Romania - perceptions and attitudes”; the survey was conducted on a sample of 1201 people, in 44 towns and 52 villages, with an error of $2,9 \%$, at a trust level of $95 \%$. The survey showed that over $65 \%$ of the population does not feel owed to help people with disabilities; $44 \%$ of the respondents feel mercy / compassion for people with disabilities, 11\% illness and 7\% burdens / sufferance. Only2\% of those questioned associated the idea of normality with this category of people. 79.9\% would not marry (or any relative) someone with a mental illness, 57\% do not want to be friend withsomeone with a mental disability, 44.2\% does not want a neighbor with a mental disability and 46,9\% do not want such a work colleague. Besides Roma people, sexual 
minorities and people with HIV/AIDS, people with disabilities are the most discriminated persons in Romania (INSOMAR, 2009).

On June 27th, 2013 appears the Law200 that modifies and completes the Law $151 / 2010$ on specialized integrated health, education and social servicesfor people with ASD and associated mental disorders. The most important changes brought the Law 200/2013 would be the elimination of the 0-3 year period for which the Law 151 applied, the present law addressing to "children with ASD and associated mental disorders", without other limitations(art. 2). The second paragraph of the $4^{\text {th }}$ article is modified, thus becoming: (2) „All persons diagnosed with ASD and associated mental disorders have free access to specialized integrated health, educational and social services mentioned by article 2. Access to education includes the right to education". Although this isan important step forward, neither this law clarifies all problems, nor offers practical solutions to implement the measures.

In 2013 The Directorate General For Internal Policies, Policy Department C: Citizens' Rights And Constitutional Affairs realized a comparative study in 18 European states (including Romania), concerning Member States' Policies for Children with Disabilities, examined in relation to the obligations arising from the United Nations Conventions on the Rights of the Child and on the Rights of Persons with Disabilities. The research identified a broad recognition of the rights of children with disabilities under national legal systems either through general or specific legislation. However, their practical implementation revealed to be problematic in most Member States resulting in obstacles faced by children with disabilities in their day to day life.

The analysis showed that in Romania, from the point of view of legislation and procedures, the best interests of the child with disabilities are a priority, with social protection measures in the family and criminal proceedings, decisions concerning social protection and education of the child. InRomania there is the National Council for the Fight against Discrimination, which manages effective complaint mechanismsto deal with discriminatory acts. The lack of funds affects accessibility to information and communication technologies requires improvements in order to enable children with disabilities to fully participate in society. With regard to the general recognition of the right 
to be heard or express views in all decisions affecting them (the first criterion), Romania has fully and effectively implemented the right of children to be heard. The general right to assistance for children with disabilities is fully and effectively implemented throughout the Romanian Constitution.

In Romania, persons with disabilities living in rural areas have difficulties in accessing social protection services as offices of the competent authorities are mostly located in urban areas. According to the study, Romania is also confronted with a lack of specialized medicosocial personnel;for diagnosis of this disorder detailed methodology has not been elaborated.

As for the access of children in Romania to inclusive education, although much debated and promoted in Europe, it is extremely limited. The study revealed that in Romania two thirds of all children with disabilities follow special education programs. The curricula for children with disabilities have not been changed for the past 20 years, while the methodology used by teachers is more than 10 years old. It is surprising that the main source of information in this respect is collected from media (TVR, 2012).

The integration of these children in mass education, although stipulated by law, is not practically achieved, studies revealing for Romania cases of denial of registration, expulsion or pressure put on parents to enroll the child in special education facilities (Ballesteros, Jurkiewicz, Meurens, 2013).

Romania has made important steps to improve the quality of life for children with autism, involving in the program Autism Spectrum Disorders in Europe (ASDEU) (20152018), aiming to investigate autism prevalence, costs, diagnosis and interventions throughout Europe. The program included 14 countries, the institution that participated from Romania being the Victor Babeș National Institute of Pathology. The investigation undertaken within the program showed that ASD prevalence estimates varies from 4.4 19.7 (percentiles 10 and 90) per 1,000 aged 7-9 years; direct costs range from $€ 797$ in Romania to $€ 11,189$ in Denmark per individual for six months; although most European countries adhered to the European Parliament's Written Declaration on Autism, the promotion and respect to autistic people`s rights by EU Member States is not satisfactory or 
evenly spread, with only a few countries (Romania is not among them) having adopted autism plans, strategies and legislation(Manuel Posada de la Paz, 2018).

On October $4^{\text {th }}, 2016$, it was given the Order 1985,to approve the methodology for evaluation and integrated intervention for granting children a grade disability, school and professional orientation of children with specific educational requirements, as well as for habilitation and rehabilitation of children with disabilities and / or special education requirements. Although autism is not individualized by the Order, its provisions also apply for autistic children. In Chap. I, Art. 2, parag. 3 it is stated that "the present order promotes the expression "children with disabilities" for a unified approach, but, in direct relationship with children, use of positive terms is suggested, such as "children with different abilities", and, according to CIF-CT, children have the right to be named as they or their parents/legal representatives want". The document reaffirms the right of children with disabilities to follow mass education (art. 18, lit. b), suggesting support measures ${ }^{5}$,for preventing and fighting against attitude barriers and environment barriers" (art. 39, parag. 3)(Order 1985/2016)

Our study reveals several important ideas for the situation of people, and especially children with ASD in Romania: although Romania has adhered to all European documents, and Romanian legislation is one of the most elaborated in this respect, unfortunately there are not enough methodologies to practically apply all these provisions; the effective implementation of legislative provisions is only partially implemented; autistic children are still victims of discriminations; the lack of specialized personnel is strongly felt.

\footnotetext{
5"Support measures for preventing and combating attitudes barriers include at least: a) informing parents whose children attend the educational establishment on inclusive education and social inclusion of children with disabilities and / or ESCs; b) inform pupils in the education unit about inclusive education and social inclusion of children with disabilities and / or ESCs, in an age-appropriate language and preferably using peer education; c) informing the management of the educational unit and the teaching staff about inclusive education and social inclusion of children with disabilities and / or ESCs; d) the presence of the facilitator, named "shadow", along with the child in the educational establishment. (3) Other measures to support the prevention and combating of attitudes barriers are awareness raising campaigns and awareness campaigns on the acceptance of diversity, social inclusion of children with disabilities and / or community-based ESCs"(art. 63, parag. 2-3).
} 


\section{References}

Autism Europe(2016). Autism-Europe's Response To The Proposal For A European Accessibility Act,http://www.autismeurope.org/wp-content/uploads/2016/02/ae-position-paper-accessibility-act1.pdf

Autism Europe, http://www.autismeurope.org/what-we-do/rights-promotion/european-accessibility-act/, accessed at 12.12.2018.

Autism-Europe $(1992,1996)$.Charter for Persons with Autism, http://www.autismeurope.org/wpcontent/uploads/2017/08/charter-for-persons-with-autism-1.pdfaccessed at 12.12.2018.

Ballesteros, M., Jurkiewicz, K., Meurens, M. (2013). Member States Policies for Children with Disabilities. Study,http://www.europarl.europa.eu/RegData/etudes/etudes/join/2013/474416/IPOLLIBE_ET(2013)474416_EN.pdf, accessed at 15.12.2018

Barthelemy, C.; Fuentes, J.; Howlin P.; Rutger van der Gaag (2000). Persons with autism spectrum disorderIdentification, Understanding, Intervention, http://www.autismeurope.org/wpcontent/uploads/2017/08/persons-with-autism-spectrum-disorders-identification-understandingintervention.pdfaccessed at 12.12.2018.

Bilde, D. et al. (2016), Written Declaration, under rule 136 of Parliament's Rules of Procedures, on Asperger Syndrome, http://www.europarl.europa.eu/sides/getDoc.do?pubRef=\%2F\%2FEP\%2F\%2FNONSGML\%2BWDECL\%2BP8-DCL-20160099\%2B0\%2BDOC\%2BPDF\%2BV0\%2F\%2FEN, accessed at 14.12.2018

European Commission (2010).European Disability Strategy 2010-2020: A Renewed Commitment to a BarrierFree Europe, https://eur-lex.europa.eu/LexUriServ/LexUriServ.do?uri=COM:2010:0636:FIN:en:PDF, accessed at 12.12.2018.

Gherca (2011). http://autismancaar.ro/ro/wp-content/uploads/2011/09/Carmen prezentare-conferintaFocsani-2.ppt

Hotarârea nr. 1251/2005 privind únele măsuri de îmbunătăţire a activităţii de învăţare, instruire, compensare, recuperare și protecţie specială a copiilor/elevilor/tinerilor cu cerinţe educative speciale din cadrul sistemului de învătământ special și special integrat.Publicat în Monitorul Oficial, Partea I nr. 977 din 03.11.2005.

http://www.autismeurope.org/wp-content/uploads/2017/08/persons-with-autism-spectrum-disordersidentification understanding-intervention.pdf, accessed at 12.12.2018.

INSOMAR (2009), Fenomenul discriminării în România. Percepţii și atitudini, https://ecitydoc.com/download/fenomenul-discriminarii-n-romania-percepii-i-atitudini pdf, accessed at 17.12 .2018

Legea Nr. 200 pentru modificarea și completarea Legii nr. 151/2010 privind serviciile specializate integrate de sănătate, educație și sociale adresate persoanelor cu tulburări din spectrul autist și cu tulburări de sănătate mintală asociate PUBLICAT ÎN MONITORUL OFICIAL NR. 396 din 01 iulie 2013

Legea $n r .448 / 2006$ republicată în 2008, legea privind protecția și promovarea drepturilor persoanelor cu handicap - Republicată în Monitorul Oficial, Partea I nr. 1 din 03/01/2008 - Modificat prin: OUG nr. $86 / 2008$

Posada de la Paz, M. (2018). Autism Spectrum Disorders in the European Union (ASDEU) http://asdeu.eu/wpcontent/uploads/2015/04/WP4M30 AutismPlansStrategiesandDisabilityPolicies ASDEU ReportSummary_Jan18.doc.

Morgan, H.; Manikiza, J.;Cassidy, A. (2012). National Autism Strategies Informing a Strategy for Autism in Europe,http://www.autismrpphub.org/sites/default/files/resources/brussels6novreport jan2013.pdf, accessed at 17.12.2018

Onu, L. (2009). Situaţia persoanelor cu autism în România 
http://www.pentruvoi.ro/uploads/files/Situatia persoanelor cu autism in Romania Laila Onu Fundatia P entru Voi1.pdf, accessed at 15.12.2018

ORDIN Nr. 1985/1305/5805/2016 din 4 octombrie 2016 privind aprobarea metodologiei pentru evaluarea şi intervenţia integrată în vederea încadrării copiilor cu dizabilităţi în grad de handicap, a orientării şcolare şi profesionale a copiilor cu cerinţe educaţionale speciale, precum şi în vederea abilitării şi reabilitării copiilor cu dizabilități şi/sau cerinţe educaţionale speciale, http://www.cjraeiasi.ro/userfiles/ORDIN\%201985130558052016\%20Metodologia\%20privind\%20evaluarea\%20si\%20orientarea\%20scolara.pdf, accessed at 10.12.2018

Roleska M, Roman-Urrestarazu A, Griffiths S, Ruigrok ANV, Holt R, van Kessel R, et al. (2018). Autism and the right to education in the EU: Policy mapping and scoping review of the United Kingdom, France, Poland and Spain. PloS ONE 13(8): e0202336. https://doi.org/10.1371/journal.pone.0202336

Ștefănescu, F., \&Oșvat, C. (2011), Socioeconomic Implications of Autism Case Study on Romanian Realities, Revista de Asistenţă Socială, vol. 2, http://www.swreview.ro/index.pl/socioeconomic implications of autism case study on romanian rea lities accessed at 15.12 .2018

TVR news, (2012).'The teaching of children with special needs in after school programmes is two decades old', http://stiri.tvr.ro/copiii-cu-nevoi-speciale-invata-dupa-programe-scolare-vechi-de-douadecenii 22259.html\#view, accessed at 15.12.2018. 